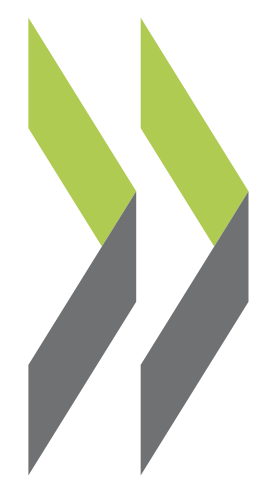

OECD Economics Department Working Papers No. 623

$$
\begin{array}{r}
\text { India's Growth Pattern } \\
\text { and Obstacles to Higher } \\
\text { Growth }
\end{array}
$$

\section{Sean Dougherty,} Richard Herd, Thomas Chalaux, Abdul Erumban 
Organisation de Coopération et de Développement Économiques

Organisation for Economic Co-operation and Development

11-Aug-2008

ECONOMICS DEPARTMENT

English - Or. English

Cancels \& replaces the same document of 04 August 2008

INDIA'S GROWTH PATTERN AND OBSTACLES TO HIGHER GROWTH

ECONOMICS DEPARTMENT WORKING PAPERS No. 623

By

Sean M. Dougherty, Richard Herd, Thomas Chalaux and Abdul Azeez Erumban

All Economics Department Working Papers are available through OECD 's Internet Web Site at www.oecd.org/econ/Working_Papers

JT03249513

Document complet disponible sur OLIS dans son format d'origine

Complete document available on OLIS in its original format 


\section{ABSTRACT/RÉSUMÉ \\ India's growth pattern and obstacles to higher growth}

India's growth performance has improved significantly over the past 20 years, but has been uneven across industries and states. While some service industries, notably in the information and communications technology sector, have become highly competitive in world markets - yielding considerable gains for employees and investors - manufacturing industries have lagged and improved their performance only recently. A divergence in performance has taken place, with firms in those states and sectors with the best institutions gaining, and those in the more tightly regulated states and sectors falling further behind. As a result, the competitive landscape is uneven across sectors and states and a high degree of concentration continues to prevail in different industries. While this is partly the result of the legacy of licensing, change has been politically difficult, making it harder for the manufacturing sector than for the service sector to expand. The need for further institutional reforms is urgent, focusing on product and labour market regulations at the central and state levels.

This working Paper relates to the 2007 Economic Survey of India (www.oecd.org/eco/surveys/india).

JEL classification: D4; F15; L11; O12.

Keywords: Manufacturing development; firm microdata; productivity; specialisation; regional concentration; regulation.

\section{Profil de croissance de l'Inde et obstacles à une accélération de la croissance}

La croissance en Inde s'est sensiblement améliorée depuis une vingtaine d'années, mais les performances sont inégales d'un secteur ou d'un État à l'autre. Si certaines industries de services, notamment dans le secteur des technologies de l'information et des communications, sont désormais très compétitives sur les marchés mondiaux - à l'origine de gains considérables pour les salariés et les investisseurs - les industries manufacturières restent à la traîne et n'ont commencé que récemment à améliorer leur performance. Les écarts se sont creusés, les entreprises des États et secteurs dotés des institutions les plus efficaces allant de l'avant, tandis que celles des États et secteurs plus strictement réglementés accusaient plus encore leur retard. D'où un paysage concurrentiel fort dissemblable d'un secteur ou d'un État à l'autre, et une forte concentration, notamment aux mains de la puissance publique, dans plusieurs secteurs d'activité. S'il faut y voir pour une part un héritage du système des autorisations administratives, les évolutions ont été politiquement délicates, rendant plus difficile l'expansion du secteur manufacturier que celle du secteur des services. Il est impératif de poursuivre les réformes institutionnelles, en privilégiant la réglementation des marchés de produits et du travail, aux niveaux aussi bien de l'administration centrale que des États.

Ce document de travail se rapporte à l'Étude économique de l'Inde 2007 (www.oecd.org/eco/etudes/inde).

Classifications JEL : D4; F15; L11; O12.

Mots clés: Développement industriel; micro-données d'entreprise; productivité; spécialisation; concentration régionale; réglementation.

Copyright OECD 2008

Application for permission to reproduce or translate all, or part of, this material should be made to: Head of Publications Service, OECD, 2 rue André-Pascal, 75775 Paris Cedex 16, France. 


\section{TABLE OF CONTENTS}

Productivity gains from shifting labour out of agriculture have been modest ........................................ 5

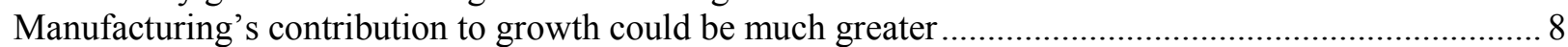

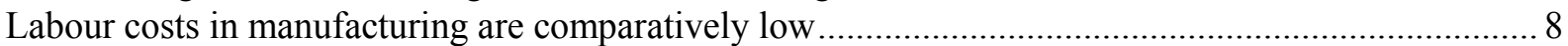

Manufacturing has not fully exploited its comparative advantage ..................................................... 10

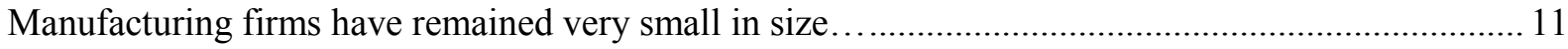

Individual firms and industries benefited from reforms .................................................................. 14

Productivity-enhancing resource reallocation nevertheless remains low ......................................... 15

High concentration in industries reduces productivity gains from liberalisation ................................. 17

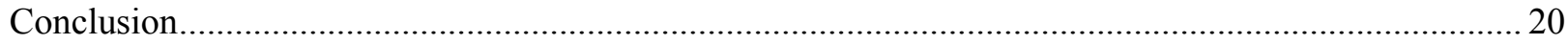

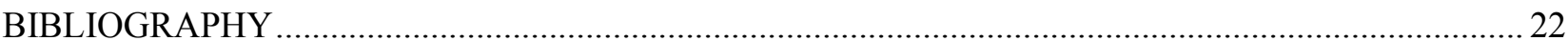

\section{Tables}

1. Labour productivity and employment shares by industry and institutional sector................................ 7

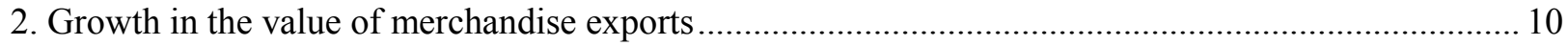

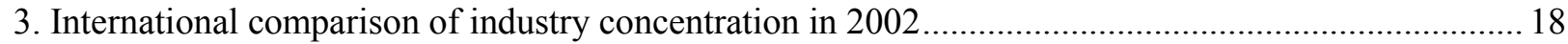

\section{Figures}

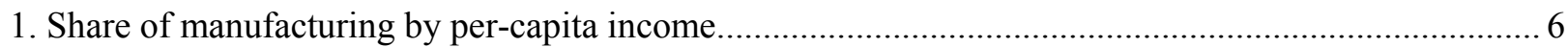

2. Relative employee compensation, productivity and unit labour costs ............................................... 8

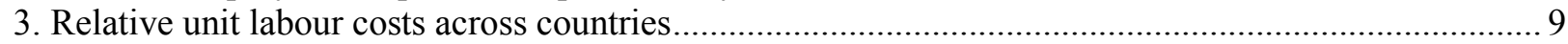

4. International comparison of the distribution of firm size in manufacturing...................................... 12

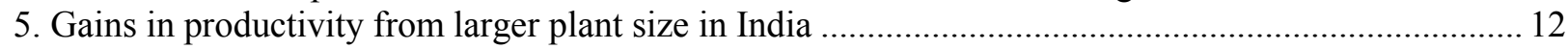

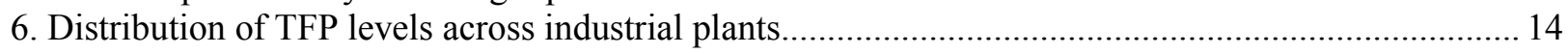

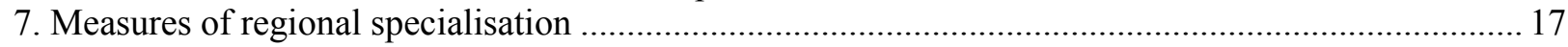

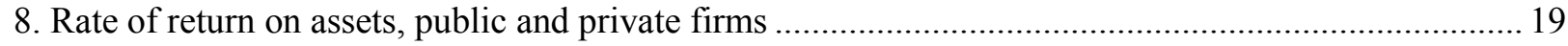


ECO/WKP(2008)31 
ECO/WKP(2008)31

\title{
INDIA'S GROWTH PATTERN AND OBSTACLES TO HIGHER GROWTH
}

\author{
by Sean M. Dougherty, Richard Herd, Thomas Chalaux and Abdul Azeez Erumban ${ }^{1}$
}

This paper examines India's growth performance and identifies areas where further reforms could enhance growth and make it more balanced. The first section looks at production in different sectors of the economy and finds that India has been following a unique development path, with the share of manufacturing in total output not increasing as income levels increase. The next section discusses possible reasons for this and finds that there are deeply-rooted problems in manufacturing that have constrained its development, although some of these have been eased with reforms. India's manufacturing firms were not able to fully exploit their comparative advantage of low labour costs and have remained extraordinarily small in scale - yet capital-intensive - restraining productivity gains as well as job creation. In the past five years, employment has expanded, driven by some liberalisation of labour laws, but many of the new jobs are of low quality (casual employment, outside the formal sector with very low wages), and few have legal protection. For large firms, substantial obstacles to restructuring employment endure, limiting their ability to compete effectively.

\section{Productivity gains from shifting labour out of agriculture have been modest}

The literature on economic development has generally argued that catch-up is associated with shifts of production away from agriculture into manufacturing and - at a later stage of development - from manufacturing into services. This so-called Three-Sector (or Fisher-Clark-Kuznets) Hypothesis appears consistent with cross-country evidence (Figure 1). It can be related to demand shifts and productivity differentials: the resource shift out of low-productivity agriculture into high-productivity manufacturing should boost overall productivity in emerging countries.

On this basis, India's development path appears to be somewhat unusual as the production shift from agriculture into manufacturing has proceeded more slowly than in most other countries at a similar stage of development while that to services has proceeded more rapidly, suggesting that India's "industrial revolution" may still lie ahead. India's manufacturing share in GDP was half a standard deviation above the mean in 1975, yet has fallen to just above the mean in recent years, as its manufacturing industry grew slowly. Some observers have therefore questioned whether India's share of manufacturing is really so outof-line with international experience (Kochhar et al., 2006). Figure 2.1 suggests that India's share of manufacturing in GDP does not appear particularly out-of-line at present. However, India is a large continental economy, and in comparison with other large economies, its manufacturing share is only a little over half that of China, Indonesia, Malaysia, Thailand, as well as Korea. Moreover, in comparison with East Asia, India has experienced weaker growth in manufacturing output and employment (Saxena and Goswami, 2007).

1. Special thanks to Willi Leibfritz and Marcel Timmer for facilitating parts of this work. Comments by Agnès Belaisch, Andrew Dean, Vincent Koen, Val Koromzay and Jean-Luc Schneider most appreciated. Authors are with the OECD Economics Department exceptAbdul Azeez Erumban, who is with the Groningen Growth and Development Centre. This paper is based largely on material from the OECD Economic Survey of India published in October 2007, and was prepared with technical support from Nadine Dufour. 
Figure 1. Share of manufacturing by per-capita income

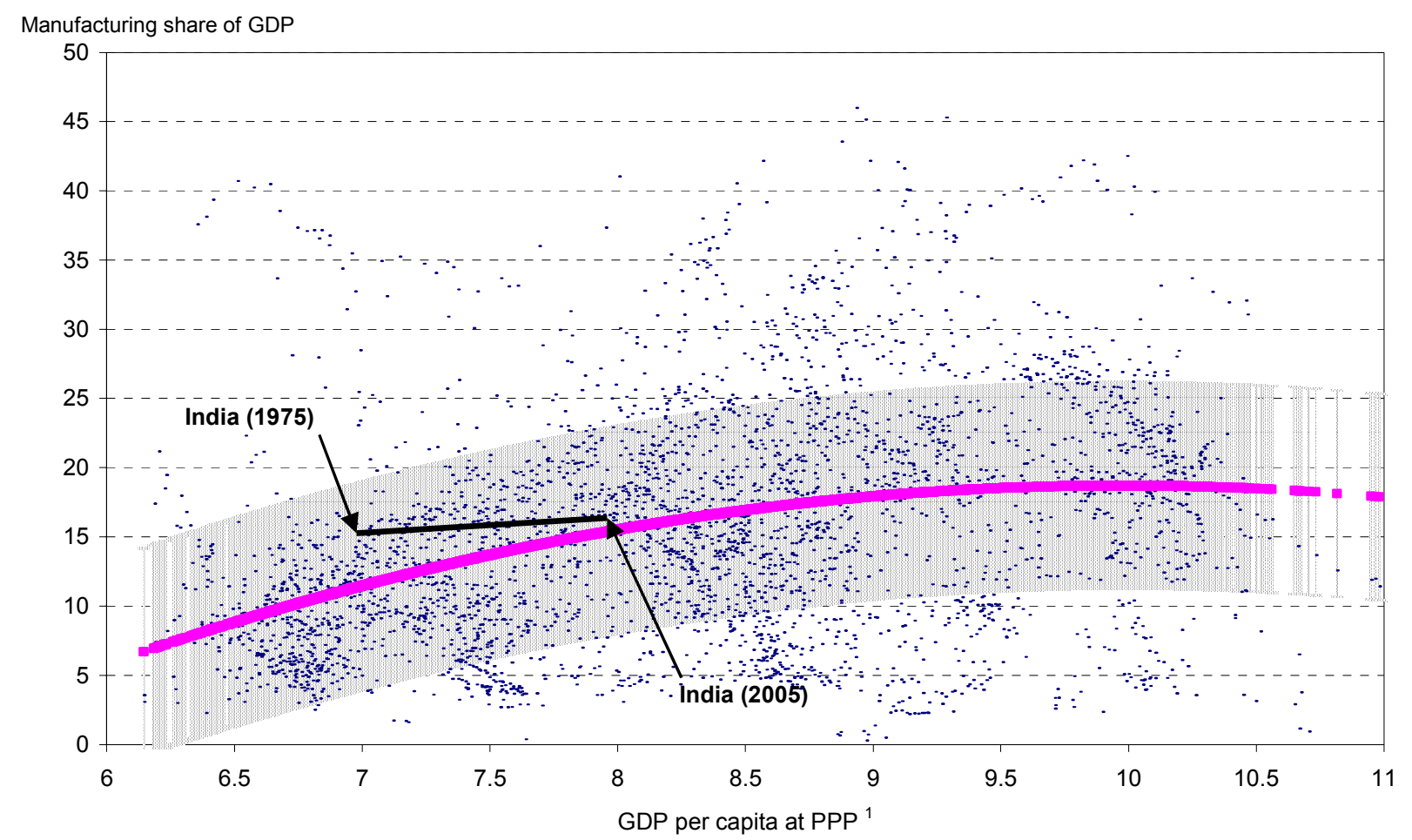

Note: Per-capita income is in thousands of US dollars at constant year 2000 purchasing power parity; shaded area represents one standard deviation around second-order polynomial trend of country observations.

Source: World Development Indicators (2007).

However, the Three-Sector Hypothesis has been widely questioned as well. One problem is its reliance on local currency prices when making comparisons, which can be misleading. When international prices are used so that adjustments are made for the fact that services prices tend to rise over time as economies become more integrated with global markets - often called the Balassa-Samuelson effect - it would appear that, rather than going up with income, the real share of services in output remains nearly constant (Heston and Summers, 1992; Hsieh and Klenow, 2007a).

Even more fundamentally, in the case of India, there are different views about the effect of resource shifts on productivity. A first look at the sectoral distribution of employment and productivity suggests that India has indeed been able to increase its overall productivity through labour reallocation. Given the higher level of productivity outside the agricultural sector, the shift of employment from agriculture to manufacturing and services appears to have boosted labour productivity growth by $0.9 \%$ per year, accounting for about one quarter of overall labour productivity growth between 1978 and 2003 (Table 1, top panel). A more detailed analysis, using census rather than sample survey information, removing housing services from output and disaggregating the data to a greater extent, found a slightly higher contribution to productivity growth from the sectoral shift in employment (De Vries and Timmer, 2007), and suggested that, prior to reforms in the mid-1980s, there was little gain in productivity due to sectoral reallocation. Bosworth and Collins (2008) also found that between 1993 and 2004 the reallocation of workers from agriculture to industry and services contributed 1.2 percentage points to annual productivity growth in both India and China. 
ECO/WKP(2008)31

Table 1. Labour productivity and employment shares by industry and institutional sector

\begin{tabular}{|c|c|c|c|c|c|c|}
\hline \multirow[b]{3}{*}{ By industry } & \multirow{2}{*}{\multicolumn{2}{|c|}{$\begin{array}{l}\text { Level of productivity } \\
\text { Net product per } \\
\text { person, } 1999 / 2000 \\
\text { prices, rupees }\end{array}$}} & \multicolumn{2}{|c|}{$\begin{array}{c}\text { Share of } \\
\text { employment }\end{array}$} & $\begin{array}{l}\text { Change in } \\
\text { productivity }\end{array}$ & $\begin{array}{l}\text { Change in } \\
\text { employment } \\
\text { share }\end{array}$ \\
\hline & & & \multicolumn{2}{|c|}{$\begin{array}{l}\text { Per cent of total } \\
\text { employment }\end{array}$} & \multicolumn{2}{|c|}{ Per cent per year } \\
\hline & 1993 & 2003 & 1993 & 2003 & \multicolumn{2}{|c|}{1993 to 2003} \\
\hline Primary & 15015 & 17749 & 64.3 & 58.0 & 1.7 & -1.0 \\
\hline Secondary & 33039 & 40036 & 14.9 & 18.1 & 1.9 & 2.0 \\
\hline Tertiary & 71171 & 113771 & 20.8 & 23.9 & 4.8 & 1.4 \\
\hline Whole economy & 29399 & 44706 & 100.0 & 100.0 & 4.3 & 0.0 \\
\hline $\begin{array}{l}\text { Whole economy with } 1993 \text { industry } \\
\text { employment weights }\end{array}$ & 29399 & 41070 & \multicolumn{4}{|c|}{3.4} \\
\hline $\begin{array}{l}\text { Productivity growth due to change in } \\
\text { employment composition by industry }\end{array}$ & & & \multicolumn{4}{|c|}{0.9} \\
\hline By institutional sector & 1993 & 2003 & 1993 & 2003 & \multicolumn{2}{|c|}{1993 to 2003} \\
\hline Informal & 20721 & 27958 & 92.6 & 94.0 & 3.0 & 0.1 \\
\hline Agriculture & 14745 & 17431 & 63.9 & 57.7 & 1.7 & -1.0 \\
\hline Other & 33989 & 44674 & 28.8 & 36.3 & 2.8 & 2.4 \\
\hline Formal & 139663 & 308099 & 7.4 & 6.0 & 8.2 & -2.1 \\
\hline Private companies & 174220 & 431699 & 2.1 & 1.9 & 9.5 & -1.3 \\
\hline Public enterprises & 148215 & 319883 & 2.7 & 2.0 & 8.0 & -2.8 \\
\hline Public services & 101756 & 186891 & 2.5 & 2.1 & 6.3 & -1.9 \\
\hline Whole economy & 29475 & 44706 & 100.0 & 100.0 & 4.3 & 0.0 \\
\hline $\begin{array}{l}\text { Whole economy with } 1993 \\
\text { institutional employment weights }\end{array}$ & 29475 & 46525 & & & 4.7 & \\
\hline $\begin{array}{l}\text { Productivity growth due to change in } \\
\text { employment composition by } \\
\text { institutional sector }\end{array}$ & & & & & -0.4 & \\
\hline
\end{tabular}

Source: National Account Statistics, National Sample Survey.

There are, however, grounds for being cautious about the extent to which labour reallocation has boosted productivity growth in India. Breaking down the economy into agriculture, the informal and the formal parts of the non-agricultural economy, huge productivity differences emerge. Productivity in the formal sector is 18 times higher than in agriculture, rising to a 25 -fold difference in the formal private company sector. An analysis of the rise in productivity based on changes in the shares of labour employed in different parts of the economy thus should take into account not only flows by industry but also the shares of the different institutional sectors within each industry.

This alternative way of looking at the changing shares of labour alters the conclusion about the impact of the movement of labour in India. Most labour has moved from agriculture to the informal nonagricultural sector and this has boosted productivity. However, at the same time, labour has moved out of the highest-productivity sector - the formal sector. The proportionate fall in formal employment was greatest in the public sector and, even in the most productive formal private sector, the share of employment has fallen slightly (Table 1, bottom panel). As a result, the overall impact of changes in employment shares has been to reduce the growth of labour productivity. One reason for the poor employment performance of the formal sector, notably private companies, may be restrictive labour legislation that has resulted in growing capital intensity. Less restrictive labour legislation might have led to increased employment and greater reallocation gains, notwithstanding the damping effect from lower capital intensity. 


\section{Manufacturing's contribution to growth could be much greater}

\section{Labour costs in manufacturing are comparatively low}

India's strongest comparative advantage could be in its labour costs, which on the basis of relative compensation at the industry level in registered (formal) manufacturing, appear to be extremely low about 1/20th of the United States' and 1/30th of Germany's (which is used in the following as a reference country) at 2002 exchange rates. However, such naïve measures of costs ignore the enormous differences in productivity levels between India and more developed countries. If productivity differences are considered by comparing effective unit labour cost (ULC) levels, the gap between India and developed countries narrows, even if it remains large. In the most recent period, India's ULC (in comparable terms) was only $16 \%$ of the level in Germany, an $84 \%$ gap. The labour cost gap is much larger than in the first half of the $1980 \mathrm{~s}$, when it was $50 \%$. The main reason for India's improved cost competitiveness was the depreciation of the Indian Rupee in the second half of the 1980s which reduced India's wage costs in foreign currency terms, while at the same time relative productivity per hour increased by $29 \%$ (Figure 2), or by $71 \%$ per employee. ${ }^{2}$

There are large differences in ULC across industries, ranging from $7 \%$ of the German level for the communications equipment sector to about $44 \%$ for the pulp and paper sector. Most of the difference reflects differences in labour productivity rather than in wage levels. One sector where wage levels are very different, however, is the unregistered informal sector. This sector includes a wide variety of trades such as tailoring and production of apparel, the processing of agricultural goods, and manufacture of various handicrafts. About one third of this unregistered sector (by value added) is officially designated as "small-scale industries" (SSIs), with about half of the remainder in the informal sector, according to standardized ILO definitions (SSI Census, 2003; Kolli and Hazra, 2005). As a result of the highly dual labour market in India, there is a five-fold wage gap between the registered and unregistered sectors, in part due to the extremely low level of labour productivity in the latter (Ray, 2004).

Figure 2. Relative employee compensation, productivity and unit labour costs

\section{Per cent of Germany \\ Panel A: Compensation per hour (at market exchange rates)}

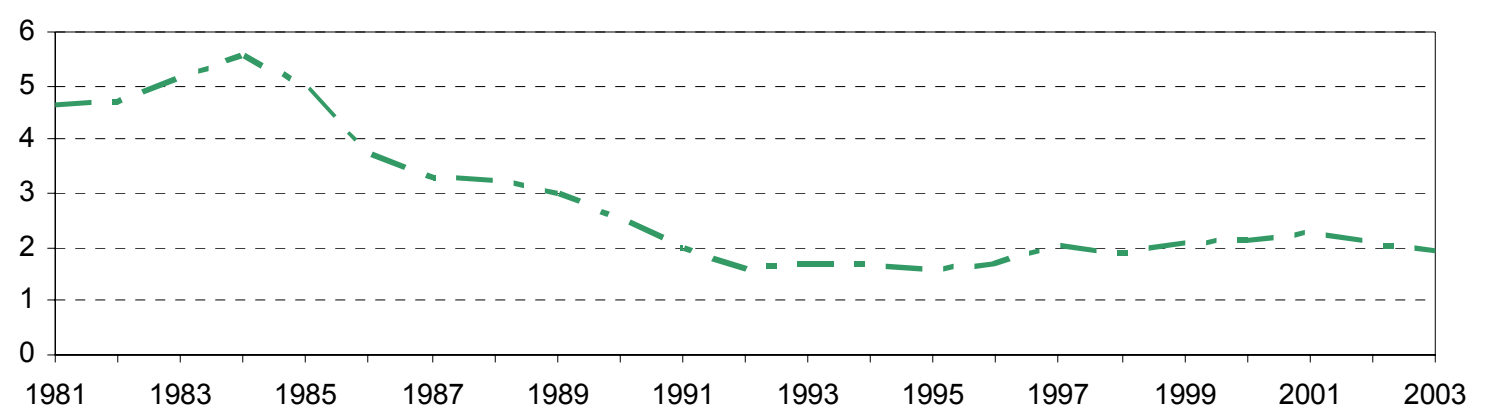

2. These ULC measures rely upon an aggregation of detailed item-by-item comparisons of manufacturing census unit values between India and Germany for almost 1000 products within 43 three-digit industrial branches. This benchmark price comparison is for the fiscal year 2002/03 and was carried out as background to OECD (2007). It is described in detail in Erumban (2007). Such measures ensure that productivity levels are assessed in comparable prices, since many goods, especially intermediate products, may not be traded and the use of market exchange rates would be inappropriate. 
Panel B: Labour productivity (hourly, at purchasing power parity)

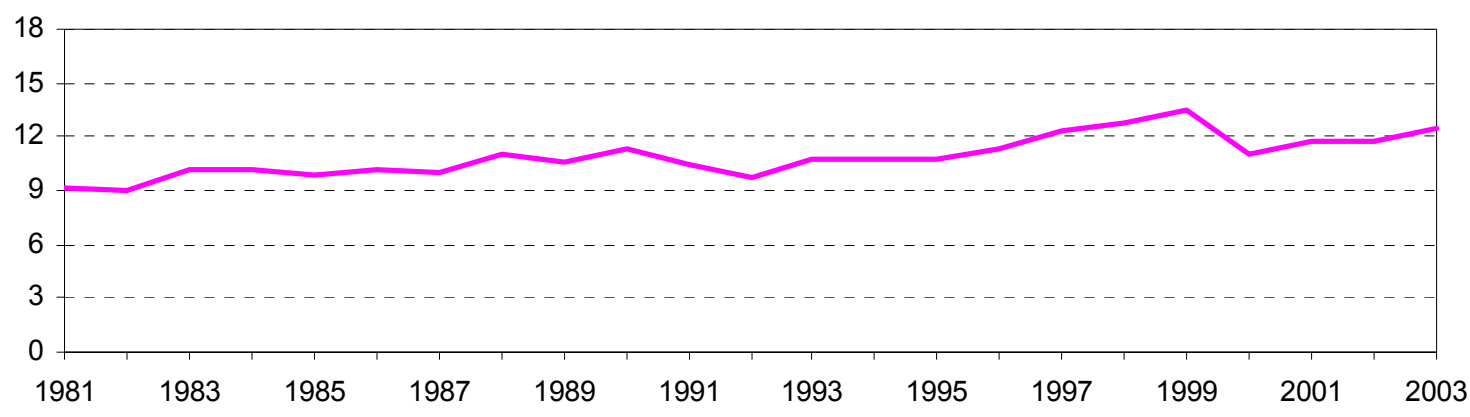

Panel C: Unit labour cost

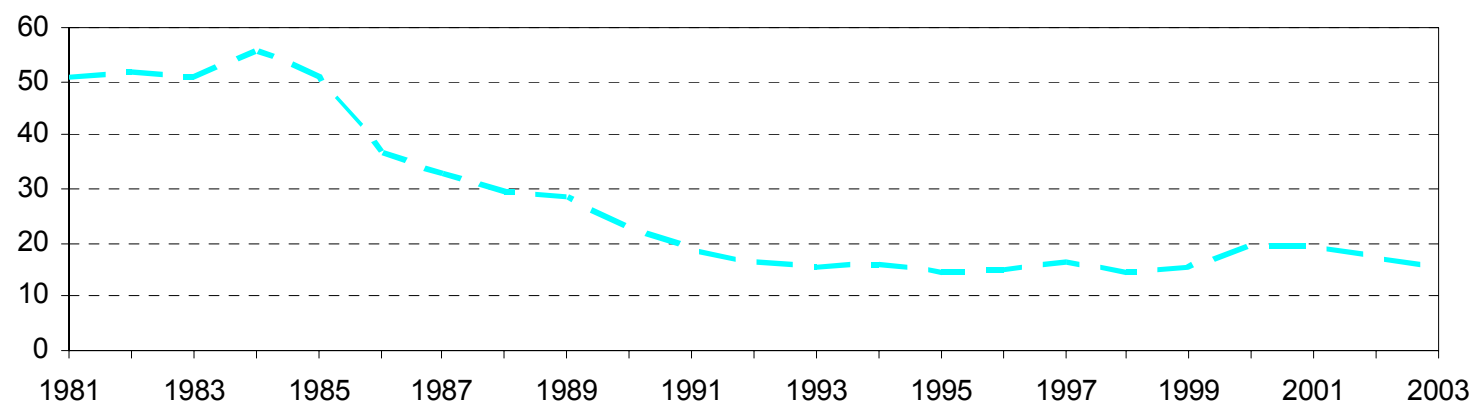

Note: Figures are for manufacturing only, excluding the petroleum industry. Source: Erumban (2007).

Even in the formal sector, India's ULC are well below those in other emerging markets, such as Mexico, Turkey or Poland - and a fortiori below those in the more developed OECD economies, although Indian ULCs are very similar to those estimated for China (Figure 3). Much of the difference with emerging OECD countries stems from lower levels of compensation per employee rather than large differences in labour productivity.

Figure 3. Relative unit labour costs across countries 2002, per cent of Germany

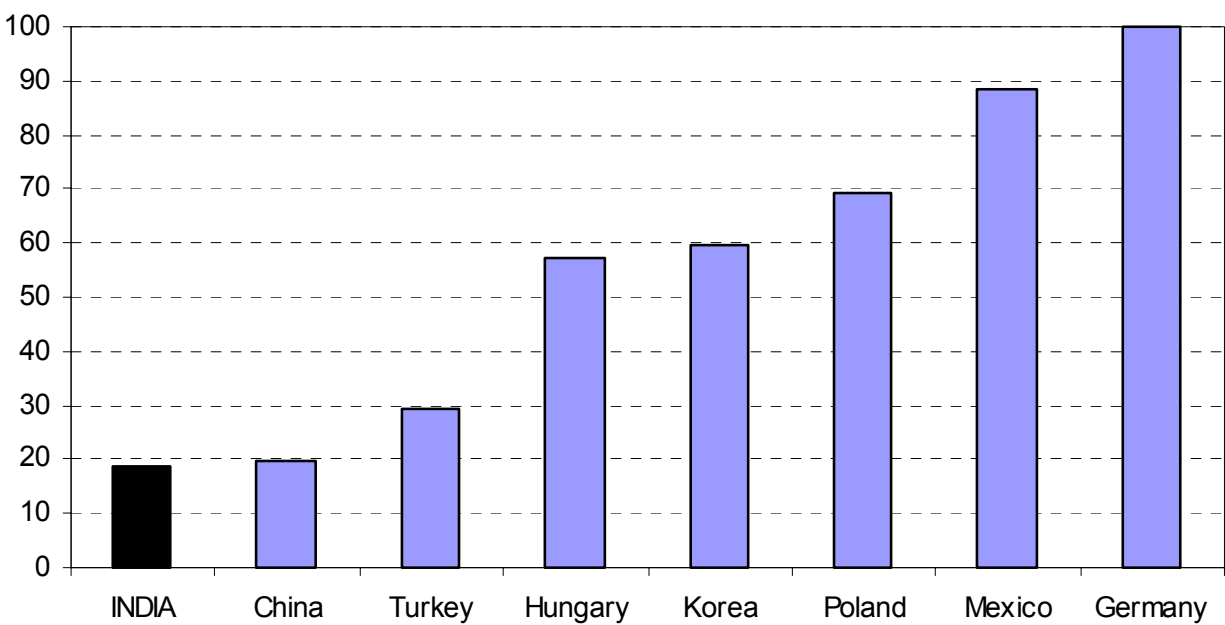

Source: van Ark et al. (2006) and OECD Productivity Database. 


\section{Manufacturing has not fully exploited its comparative advantage}

Despite these cost advantages, India's manufacturing output and exports have grown relatively slowly until this decade. A weak overall productivity performance was seen as the cause of this outcome (Nagaraj, 2004; Kochhar et al., 2006). As described earlier, in contrast to most developing countries that have increased their share of industry as they have moved out of agriculture, India's development since the 1980 s can be characterised as shifting resources directly from agriculture to services. Moreover, until this decade, export performance in manufacturing lagged behind that of East Asian countries where goods exports have been an important driver of growth (Table 2). Since the beginning of this decade, though, manufactured exports from India have grown faster than in most East Asian countries except China. As a result, the gap between the growth of manufacturing and service output has narrowed, with manufacturing even outpacing services in 2007.

Table 2. Growth in the value of merchandise exports

Per cent per year, values measured in USD

\begin{tabular}{lrrrrrr}
\hline & $1980-85$ & $1985-90$ & $1990-95$ & $1995-2000$ & $2000-05$ & $1980-2005$ \\
\cline { 2 - 7 } China & 8.6 & 17.8 & 19.1 & 10.9 & 25.0 & 16.1 \\
Turkey & 22.3 & 10.2 & 10.8 & 5.1 & 21.5 & 13.8 \\
Thailand & 1.8 & 26.5 & 19.6 & 4.1 & 9.8 & 12.0 \\
Korea & 11.6 & 16.5 & 14.0 & 6.6 & 10.5 & 11.8 \\
Hong Kong, China & 8.2 & 22.3 & 16.1 & 3.1 & 7.6 & 11.3 \\
Mexico & 8.2 & 8.8 & 14.3 & 15.9 & 5.1 & 10.4 \\
India & 1.3 & 14.5 & 11.3 & 6.7 & 17.5 & 10.1 \\
Malaysia & 3.6 & 13.8 & 20.2 & 5.9 & 7.5 & 10.0 \\
Chinese Taipei & 9.2 & 16.9 & 10.9 & 6.0 & 5.5 & 9.6 \\
Philippines & -4.3 & 12.0 & 16.6 & 17.8 & 0.7 & 8.2 \\
Pakistan & 0.9 & 15.4 & 7.4 & 2.4 & 12.0 & 7.5 \\
Brazil & 5.0 & 4.1 & 8.2 & 3.4 & 16.5 & 7.3 \\
Japan & 6.3 & 10.2 & 9.0 & 1.6 & 4.4 & 6.3 \\
Indonesia & -3.2 & 6.7 & 12.1 & 7.6 & 5.7 & 5.6 \\
\hline
\end{tabular}

Source: World Trade Organization Trade database.

However, as a result of its relatively small share in non-agricultural output, manufacturing's absolute contribution to overall output growth has been less than a third of that for commercial services in the eight years to end-2007, with its annual growth rate being two percentage points lower. Moreover, some service sectors have performed exceedingly well, with communications, for instance, contributing seven times its share of GDP towards growth during this period. The rapid growth of services does raise the question of whether India could follow a development path that essentially bypasses manufacturing, as it has led to an acceleration of overall growth. However, it would seem unnecessary and suboptimal for India to pursue such a unique path of development given its potential strengths and comparative advantages, and the need for more broad-based development to provide enough employment opportunities for its growing labour force. India's revealed comparative advantage (RCA) is, in fact, in many of the same (disaggregated) labour and resource-intensive manufacturing sectors as China's, suggesting that it could better exploit its competitive export strengths by further expanding its manufacturing sector (Batra and Khan, 2005). ${ }^{3}$

In trying to understand why India's manufacturing is lagging behind, a number of unusual characteristics of India's pattern of development appear to be symptomatic of deeper structural distortions

3. Since actual comparative advantage is difficult to measure, RCA (or the Balassa Index) is often used instead. It is defined as a country's share of world exports of a good divided by its share of total world exports. 
in the economy. These features include an extraordinarily large share of overall manufacturing employment in micro-enterprises - most of which are in the informal sector - and relatively high capital intensity in the organised sector, despite the low labour costs, with the wage share of gross value added being only $25 \%$. We examine each of these issues below, before drawing some policy conclusions.

\section{Manufacturing firms have remained very small in size...}

Perhaps the most dominant characteristic of India's manufacturing sector is the extraordinarily small scale of establishments relative to any OECD country or other emerging countries when measured in terms of employment and output (Figure 4). About $87 \%$ of manufacturing employment is in micro-enterprises of less than 10 employees, a smallness of scale that is unmatched, with the closest comparator being Korea, where less than half of employment is in micro-enterprises. While there is a fairly high share of very large companies - making for a bimodal distribution - there are few enterprises of intermediate size.

The small scale of Indian industry arose in part by design: the pre-reform licensing system meant that only one major company was allowed to operate in many industries, while other industries were reserved to small-scale industry (SSI). While these market entry restrictions have been largely dismantled, their legacy continues to reduce competition, scale and productivity in many sectors. In addition, some regulations persist, notably those related to labour and administrative approvals, which also constrain firms' growth.

Given the relatively small size of many manufacturing firms, India is not (or much less so than other countries) reaping gains from scale economies. Larger establishments often use newer technologies ${ }^{4}$ and thus achieve higher productivity, while smaller establishments are much less productive. Accordingly, although small firms' share in manufacturing employment is almost $90 \%$, they produce only about a third of manufacturing output. An estimate of scale effects for plants, based on individual establishments in the Annual Survey of Industries, shows them to be very large and persistent. Even after controlling for technology, industry, region and firms' age, total factor productivity (TFP) is about twice as high in firms with more than 250 employees than in those with only up to 10 employees, with progressive increases in scale yielding considerable gains in productivity as well (Figure 5).

The extent of potential gains from larger size is perhaps not surprising considering that anecdotal information from interviews of Indian businesses and industry experts reveal extensive fragmentation and even progressive disintegration of business operations into small subcontracting units that further exacerbates the problem and means that comparative productivity levels in some industries are much lower for purely organisation reasons (McKinsey, 2005; Mukerji, 2006). More aggregate labour productivity data on the unorganized sector from the SSI Census and NSSO data suggest that past investment restrictions on this sector have created diseconomies of scale (SSI Census, 2004). Thus, it is not surprising that SSI businesses have agreed by consensus to have their protections dismantled. Moreover, it suggests that the gains to increasing scale in the SSI sectors could be even larger than those in the registered manufacturing sector.

4. Technology use across firms is discussed in Banerjee and Duflo (2005) and Hsieh and Klenow (2007b). 
Figure 4. International comparison of the distribution of firm size in manufacturing 2002 or nearby year

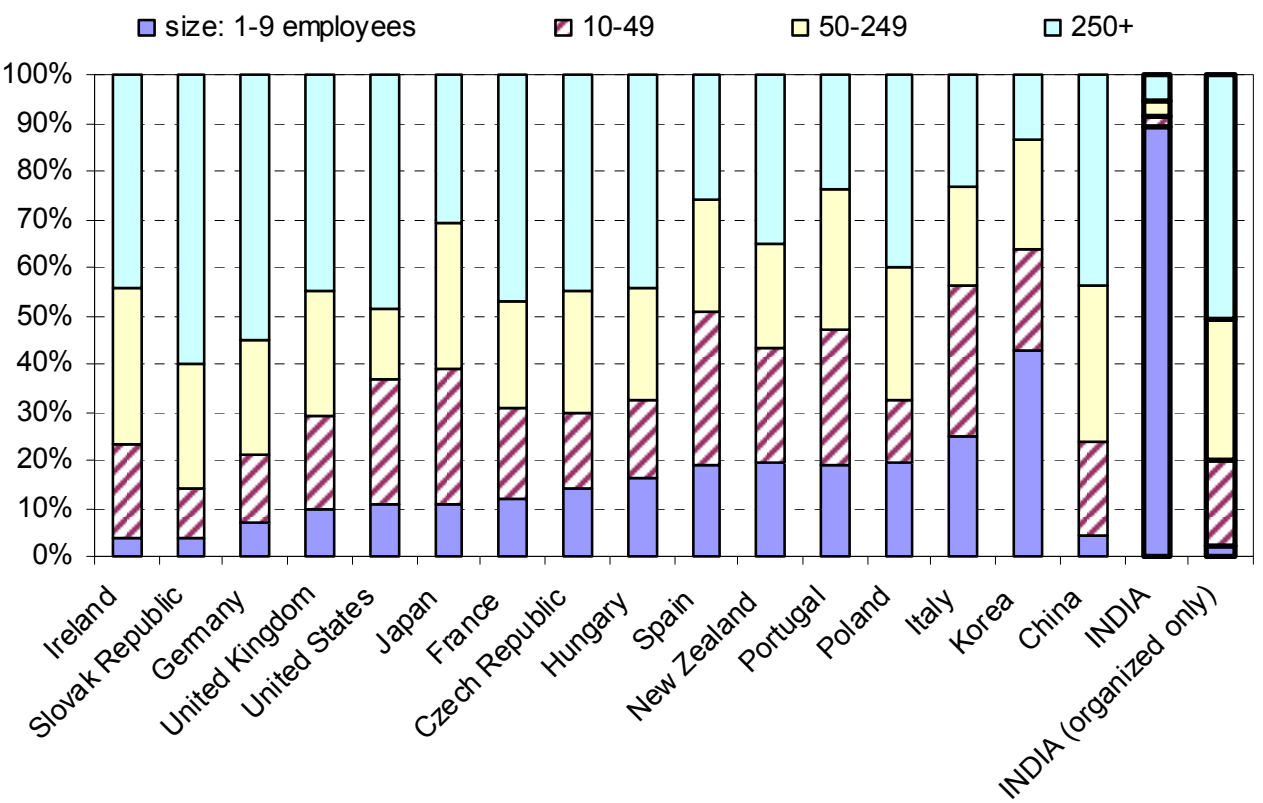

Notes: For China, India (2005) and the United States, services are included. Some countries' data does not include all microenterprises (Japan, Portugal and Korea).

Source: OECD Statistics on Enterprises by Size Class; India Economic Census (2005), China Economic Census (2004).

Figure 5. Gains in productivity from larger plant size in India

Total factor productivity (TFP) in a given plant size relative to a plant with 1 to 10 employees

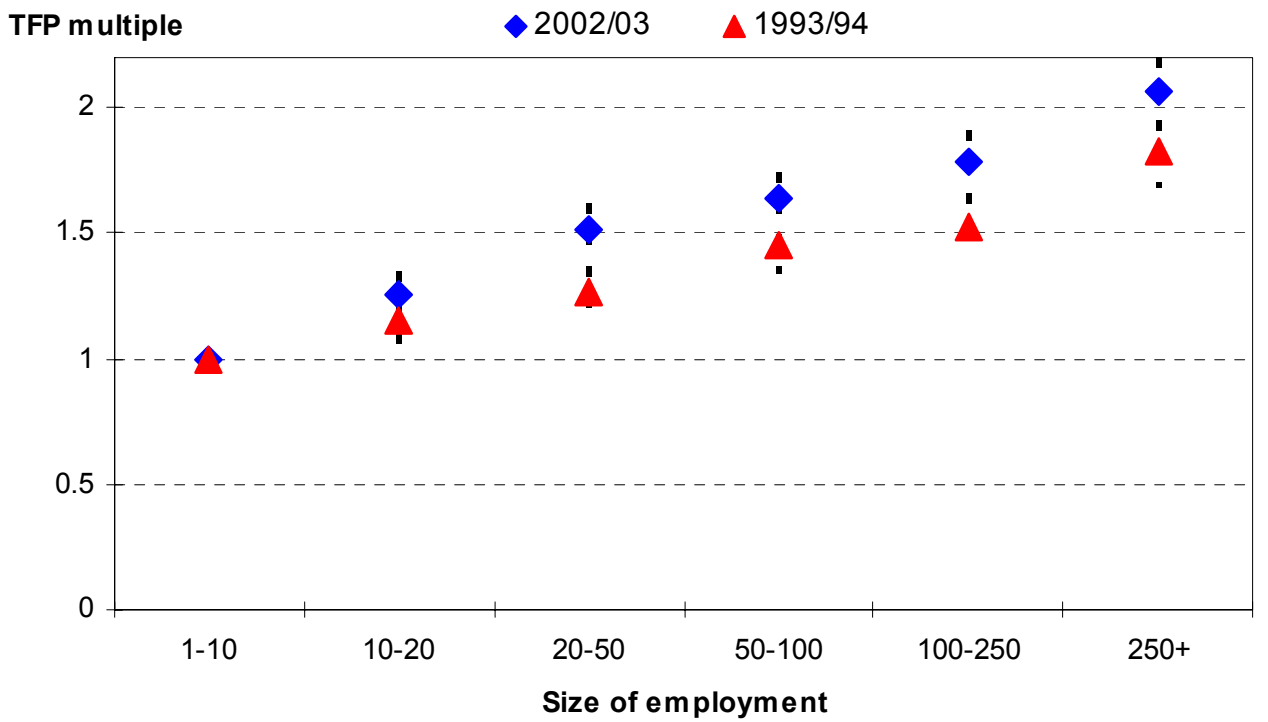

Note: The drop lines in the figure represent $95 \%$ confidence intervals.

Source: OECD estimates based on production functions estimated from Annual Survey of Industries unit level data. 


\section{...with a bias towards capital-intensive production...}

At the same time that firms in India have remained small, a large share of India's manufacturing has been in sectors that usually require a larger scale of production. ${ }^{5}$ Moreover, production has tended to be particularly capital-intensive, with the labour share of value added remaining very low, at about a quarter compared with nearly two-thirds in many OECD countries. Such a pattern of production appears out-of-line with RCA estimates that show less comparative advantage in skill-based industries relative to China (Batra and Khan, 2005). The relatively high capital intensity of manufacturing also appears out-ofline with relative prices, given that the cost of capital has been very high relative to labour costs throughout most of the economy as, until recently, prices of investment goods have were driven up by import tariffs. ${ }^{6}$

\section{....and some evidence that TFP growth may have accelerated this decade}

Labour productivity in manufacturing has doubled over the course of the past two decades. A number of studies suggest that most of this increase was due to capital deepening rather than TFP growth. While there were clear improvements in TFP growth during the 1980s, there is very little evidence of acceleration after 1991 (Kaur, 2006; Ministry of Finance, 2006). A few studies have shown a slight increase during the 1990 s as compared with the 1980s (i.e. Tata, 2003), but their methodological assumptions have been widely questioned for (see Goldar, 2004).

It is somewhat puzzling that trade liberalisation and deregulation did not raise TFP growth during the 1990 s, either for the total economy or for the manufacturing sector. However, these reforms may have increased competition. In order to examine this hypothesis, a value added production function was estimated cross-sections of all plants in the organised sector (ASI):

$$
\ln (V A)=a+\alpha \ln (L)+\beta \ln (K)+\gamma \ln (W)+D \cdot \delta+\varepsilon
$$

where VA is value added, $\mathrm{L}$ is labour input (in full-time equivalents), $\mathrm{K}$ the capital stock (based on the book value of net fixed assets), $\mathrm{W}$ the wage bill, matrix $D$ a set of control dummies for scale, time, region, and industry and $\varepsilon$ the (exponential) error term. This suggests that TFP levels across industrial firms became more equal (Figure 6), which is generally taken as a sign of increased competition through more new entry of productive firms (Bartlesman and Doms, 2000). Nonetheless, in many industries the market structure remained concentrated so that there was not enough pressure to raise TFP.

The situation may have changed after 2000. For the industrial sector as a whole it was found that TFP may have increased in from 2002 (Virmani, 2006; Poddar and Yi, 2007). Our own estimates on the basis of production functions using firm-level corporate-only data suggest an increase in annual TFP growth in the manufacturing sector from less than $1 / 2$ per cent per year during the 1990 s to around $2 \frac{1}{2}$ per cent per year during $2000-05 .^{7}$ This could imply that the opening of the economy and higher competition is finally

5. Relative to the nine developing countries producing more manufacturing value-added than India, the average value added per establishment was more than ten times greater than that in India (Kochhar et al., 2006).

6. For instance, the price of machinery capital fell from substantially above world levels in the early 1980s, by about $1 \%$ per year during the 1980 s with the initial liberalisation of capital goods imports, and by $2 \%$ per year in the 1990 s as high tariffs and quantitative restrictions were dismantled, and by $3 \%$ per year as trade opened further during the first part of this decade (Virmani, 2006). As a consequence, machinery investment rates rose in step with the decline in its price, although this uptake in investment could well have been much more rapid.

7. This result relies upon gross output production function estimates on corporate firm microdata from the Prowess database, 1990-2006. The total wage bill is used to measure labor input, while an estimate of 
bearing fruit also in terms of higher TFP growth. However, the estimates of OECD (2007) suggest less acceleration in TFP at the aggregate level, suggesting that such gains may have been limited to the largest corporations.

\section{Figure 6. Distribution of TFP levels across industrial plants}

Normalized frequency for the years 1993, 1999, 2003

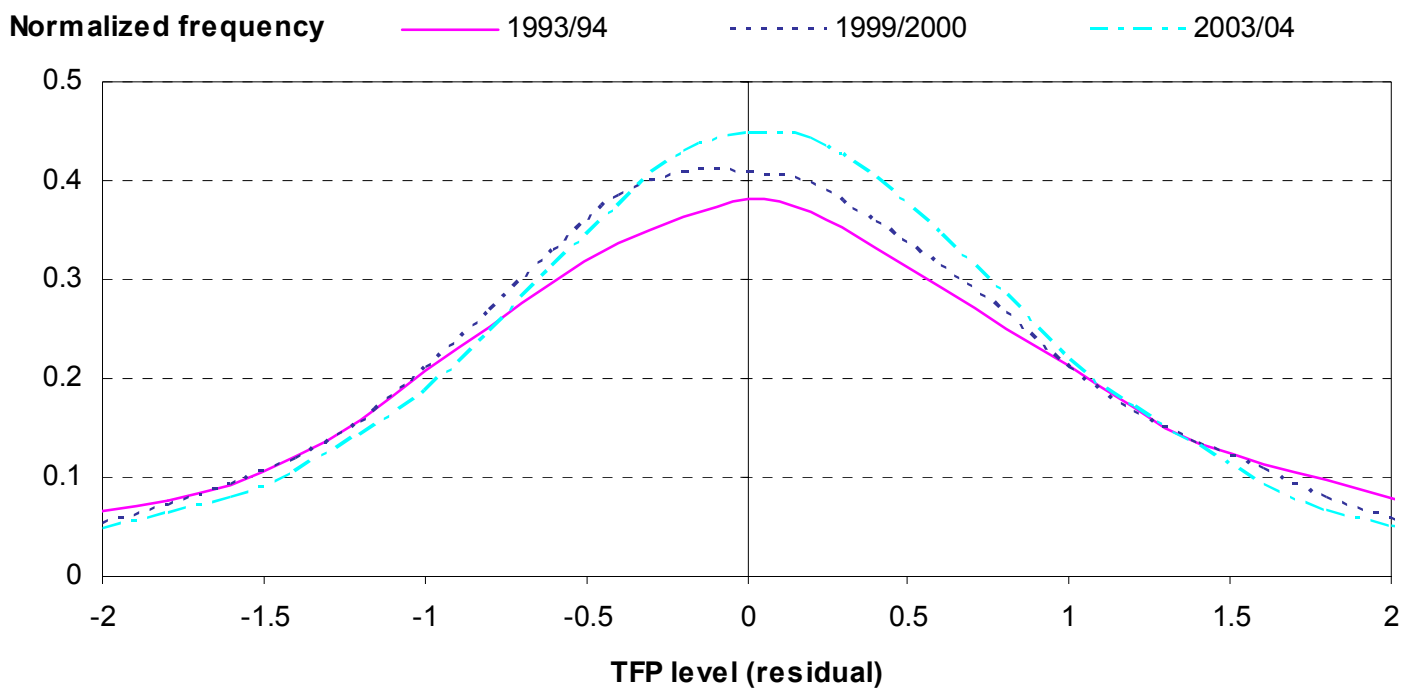

Source: OECD estimates using plant level data from the Annual Survey of Industries.

\section{Individual firms and industries benefited from reforms}

There is evidence that economic reforms had a positive effect on the productivity of some firms and industries. However, as many of the firms that coped less well with increased competition and suffered relative productivity losses remained in the market, the effect of reform on overall productivity was muted. Sivadasan $(2003,2006)$, using plant-level ASI data through the mid-1990s and structural estimates, found an improved productivity performance in industries that liberalised (through de-licensing) in comparison to those that did not. Industries that were affected by FDI liberalisation had an $18 \%$ to $23 \%$ increase in productivity, and industries that faced tariff liberalisation experienced productivity gains of around one third. The study also suggested that twice as much of the change occurred within as across plants. The lack of reallocative gains appears to be a result of the difficulty of market exit and the rigidities imposed by inflexible labour market regulations.

A strong positive impact of trade liberalisation on TFP was also found by Topalova (2004), using a firm-level panel dataset from 1989 to 2001 . She found that a $10 \%$ decrease in tariffs resulted in a $1 / 2$ per cent increase in TFP. Again, the gains accrue within existing firms rather than as result of the demise of unproductive firms, as exit rates are extremely low. Bhaumik et al. (2006a, 2006b) found a shift in the dispersion of productivity across industries since 1991 and showed that it was associated with a substantial increase in new firm entry as pro-competitive reforms impacted firm location decisions. ${ }^{8}$ In particular,

capital stock is made using available investment data. Controls for industry, region and scale are included. All data are measured in real terms using CPI for industrial workers for labour, and relevant WPIs for fixed investment, output and material inputs (weighted using the 1999 input-output table).

8. Such effects may be aggravated by the phenomenon that Burgess and Venables (2004) observe in a comparison of Indian and UK firms, where firms that were closer to the technological frontier may have 
liberalisation of entry barriers and the consequent increase in net firm entry rates had a strong positive impact on productivity, even as labour policies appear to have restrained it due to the lack of reallocation and limited exit of firms with obsolete technology. These studies all suggest that reforms led to a divergence in performance across firms in different industrial sectors and that overall productivity would have increased more had a greater number of the less productive firms exited the market.

\section{Productivity-enhancing resource reallocation nevertheless remains low}

The reallocation of resources to more productive uses that would be expected to occur in an increasingly open economy has occurred slowly. The most important reasons for this slow pace of change appear to be few firm exits, low labour migration across states and ongoing high concentration of production in some industries.

The limited impact of firm exits on productivity seen in most studies is reflected in the very low exit/hazard rates for large industrial firms, which at 3\% per year for quoted corporations (from Prowess) are many times smaller than in nearly all OECD economies and most other developing countries. This low exit rate reflects the great difficulty of closing a business in India where there is no bankruptcy code, and prior permission of the government is required before laying off workers.

Labour is highly immobile across states in India as a whole, impeding reallocation of human resources. Almost half of the migrants across states are women moving for marriage while less than $10 \%$ move to find new employment. The bulk of internal migration in India is short-distance, with $60 \%$ of migrants changing their residence within the district of enumeration and over $20 \%$ within the state of enumeration, while the remaining 20\% move across state boundaries (Srivastava and Sasikumar, 2003). Evidence from the $61^{\text {st }}$ National Sample Survey suggests that migration rates have only mildly increased over the past decade.

One often-mentioned reason for the low internal migration is the multitude of languages and dialects spoken in the country. ${ }^{9}$ However, a comparison of migration rates across the then 15 members of the European Union with that across Indian states over a recent 10-year period suggests that there was twice as much migration within Europe as within India, and that it was heavily oriented towards employment. ${ }^{10}$ Limited migration in India may lead to adverse impacts of trade liberalisation for states with heavilyprotected labour markets. And indeed, there is evidence that states with the most restrictive labour regulations experienced even less labour mobility, impeding poverty reduction (Topalova, 2004).

A rigorous means of assessing reallocation across sectors and regions in India is to use regional concentration indexes. There are two leading measures of regional concentration available in the literature (see Dougherty et al., 2007). The first is the Balassa-Hoover Index, which measures the extent to which an industry is specialised by region, with higher values of the index reflecting greater specialisation in an industry (Hoover, 1936). It is based on the location quotient $\mathrm{L}$ with respect to output, described by Bai et al. (2004), at time $t$ :

benefited more from trade liberalization than those that were further from it, feeding a divergence in productivity that may have resulted in aggregate TFP stagnating.

9. In India there are 24 major languages spoken by a million or more persons. Although Hindi is spoken by half of the population, they are concentrated in less than half of the (mainly northern) states. Official estimates suggest that between 150 and 250 million people speak English out of a population of 1.1 billion.

10. This comparison is based on analysis of OECD Labor Force Survey data for the 1995-2005 period and estimates from CSO (2001) between the 1990 and 2000 population census. 


$$
L_{i j}=\frac{Y_{i j} / Y_{i}}{Y_{j} / Y}
$$

where $Y_{i j}$ is output of industry $i$ in region $j, Y_{j}$ is total output in region $j, Y_{i}$ is total output in industry $i$, and $Y$ is total industrial output. If $L_{i j}$ is greater than 1 , then region $j$ has a higher percentage of industry $i$ than of total industrial output. The regions $j$ are arranged in order of increasing location quotients (degree of specialisation) in an industry $i$ and cumulated.

The Balassa-Hoover index for each industry is given by the Gini index of the resulting area between this curve and the 45 degree axis. This value is by definition between 0 and 1 , with a higher value representing greater specialisation by region. In order to yield an overall index, the index for each industry is then aggregated weighting by the industry's share in total output. This index is also computed using employment data in place of output data (defining $Y$ as employment rather than output). These computations are done at the two-digit industry level among provincial-level regions, for each year in the dataset.

The Ellison-Glaeser Index is an alternative regional concentration index that controls for the size distribution of firms. It is also computed, taking advantage of the firm-level data available in this study. This index yields a measure of regional concentration by industry that includes an adjustment for intra-firm heterogeneity (Ellison and Glaeser, 1997). It is defined at time $t$ as:

$$
\gamma_{i} \equiv \frac{G_{i t} /\left(1-\sum_{j} s_{j t}{ }^{2}\right)-H_{i t}}{1-H_{i t}}
$$

where the term $G_{i t}$ is the sum of squared deviations of the industry $i$ 's employment shares $s i j t$ from a measure, $s_{j t}$ of region $j$ 's share of aggregate employment: ${ }^{11}$

$$
G_{i t} \equiv \sum_{j}\left(s_{i j t}-s_{j t}\right)^{2}
$$

and the term $H_{i t}$ is a Herfindahl-style measure of the firm-level concentration of employment in an industry:

$$
H_{i t} \equiv \sum_{k} e_{k t}^{2} /\left(\sum_{k} e_{k t}\right)^{2}
$$

where $e_{k t}$ is the level of employment in the $k^{\text {th }}$ firm in industry $i$ at time $t$. These measures are computed at the three-digit industry level among provincial-level regions. They are then weighted up to the aggregate level using both firm and employment weights.

The Herfindahl-Hirschman Index (HHI) is also computed, in order to assess the degree of market concentration in an industry:

$$
H H I=\sum_{i=1}^{N}\left(100 \cdot s_{i}\right)^{2}
$$

11. Following Dumais et al. (2002), we define $s_{j t}$ as the unweighted arithmetic mean of the $s_{i j t}$ terms across the industries in the sample, $s_{j t}=(1 / I) \sum_{I} s_{i j t}$ where I is the total number of industries. 
The index is defined as the sum of the squared market shares $s i$ of each firm $i$ in an industry. Industries for which the HHI index exceeds 1800 are considered by the US Department of Justice to be highly concentrated, while those where it ranges between 1000 and 1800 are considered to be moderately concentrated (US DOJ-FTC, 1994).

Taking advantage of Annual Survey of Industries micro data, regional concentration indexes were computed across states and industries for 1990, 1994, and 1999-2004. This analysis suggests almost no change in regional specialisation using employment (or firm) weights while it shows a gradual increase in regional specialisation using output weights - likely reflecting the low extent of migration across regions (Figure 7).

On the other hand, there is evidence of growing integration of markets based on changes in retail commodity prices, likely facilitated by better telecommunications. For 24 basic commodities, price dispersion across states (as measured by the coefficient of variation) fell from 15\% to $9 \%$ between 1994 and 2004, and a simple average of the price differentials for these commodities fell from $60 \%$ to $22 \%$ (Virmani and Mittal, 2006). A broader set of non-food manufactured goods commodities suggests an even lower differential (12\%) when prices are expenditure-weighted. In China, the mean absolute price differentials across provinces was only around $7 \%$ for manufactured products although such comparisons are inexact since they are based on wholesale rather than retail prices (Dougherty et al., 2007). For agricultural products, whether in their primary or processed state, differentials across states are larger and exhibit a greater degree of variability than for non-food manufactured products. Thus, there still appears to be room for further gains in integrating domestic markets where taxation, lack of transport infrastructure and barriers to free sale of a number of agricultural products act as a brake on the extent of internal trade.

Figure 7. Measures of regional specialisation

Using the Balassa-Hoover $(\mathrm{BH})$ and Ellison-Glaeser $(\mathrm{EG})$ indices

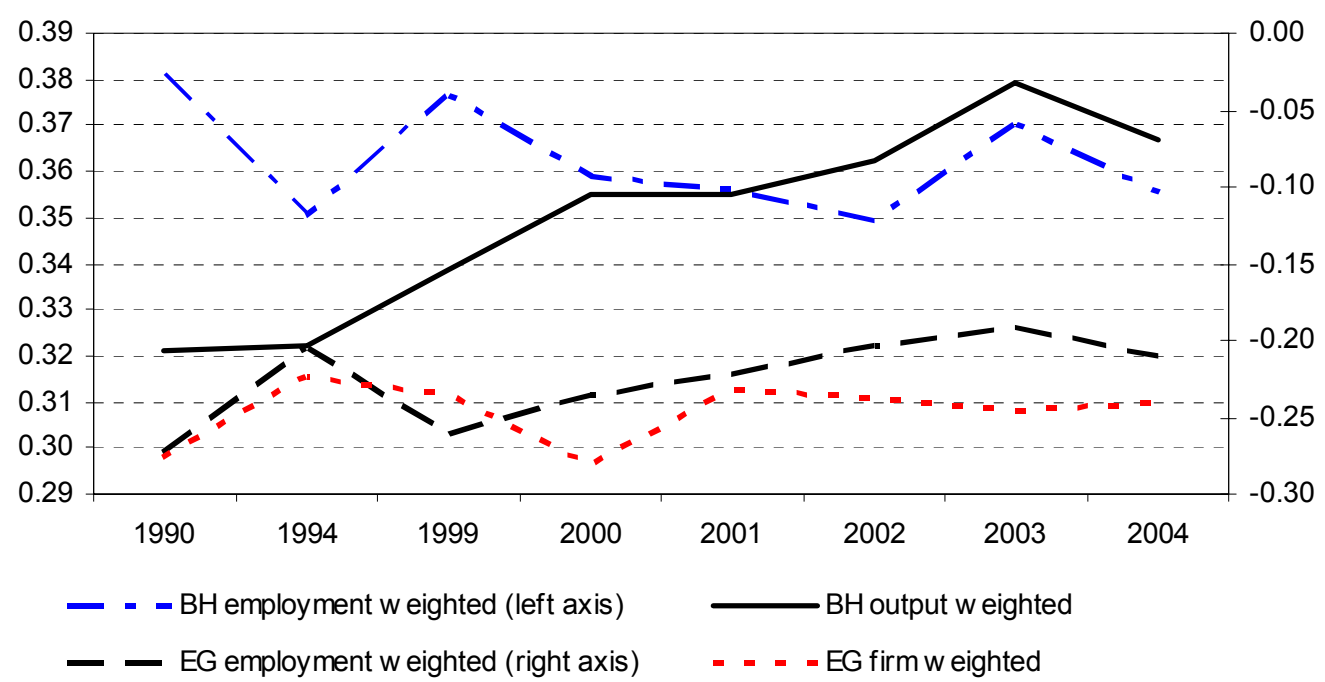

Source: OECD computation from plant level data from the Annual Survey of Industries.

\section{High concentration in industries reduces productivity gains from liberalisation}

Indicators of competition suggest that stable regional concentration has been accompanied by a stable, yet high, degree of market concentration in many Indian industries. For instance, Herfindahl indexes have high values based on standard criteria and have not fallen much over time, with about as many industries' concentration ratios rising as falling during the 1990s (Ramaswamy, 2006). Moreover, in those industries 
where market concentration has risen, one or two large firms typically dominate the market (a number of which are public sector undertakings). Similarly, average price-cost margins increased in the 1990s across virtually all two-digit manufacturing sectors (Balakrishnan and Suresh-Babu, 2003).

The studies cited above showed that tariff reduction helped to raise productivity but that the impacts varied across industries. The extent of competition in a given industry appears to be one factor impacting on the extent of productivity gains, as there is evidence that trade liberalisation has only improved firm and plant-level productivity in unconcentrated industries. Analysis of the impact of industry-specific tariffs on firm-level (corporate) productivity shows that liberalisation had a strong positive effect (through 2001), but only in private sector companies and for those in unconcentrated industries (Topalova, 2004). This may in part be due to the fact that regulations that raise entry barriers for foreign firms are more likely to be found in industries that are highly concentrated, diminishing the benefits of this potential foreign competition for consumers (Chari and Gupta, 2006).

The extent to which the output of industries is concentrated in a few firms is indeed remarkably high compared to other major economies. Applying a standard definition of concentration (a Herfindahl index of over 1800 ) to industry census data shows India's share of highly concentrated industries to be more than three times higher than that of the United States or China, and twice as high as that for Germany (Table 3, top panel). It is possible that this high degree of concentration is due to the small size of the Indian market relative to optimal plant sizes. Nonetheless, the existence of market concentration and dominant firms suggests that the possibility of anti-competitive behavior exists in many manufacturing industries.

Table 3. International comparison of industry concentration in 2002

The concentration groupings are based Herfindahl index scores, using the U.S. Department of Justice criteria

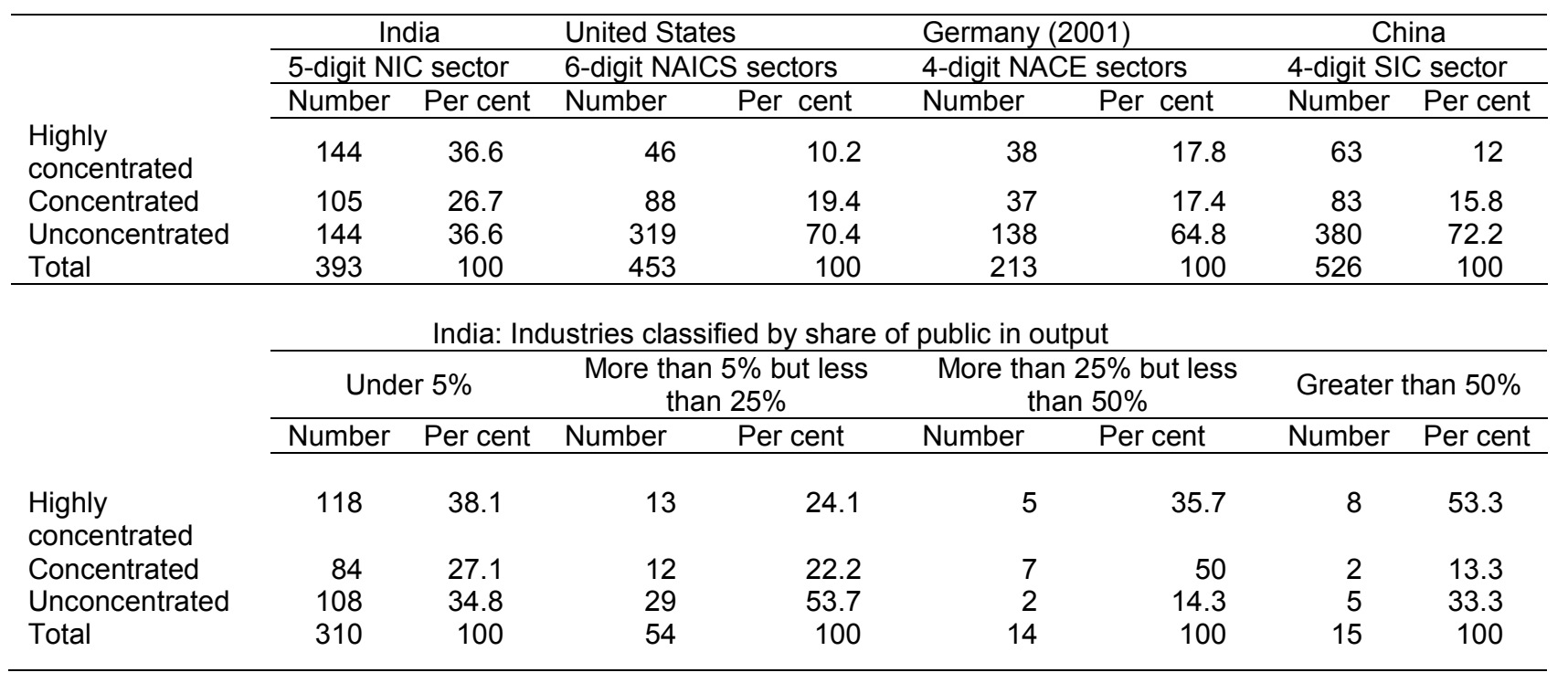

Source: OECD tabulation of Annual Survey of Industries plant-level data for India; US Census Bureau data for the United States; Deutscher Bundestag data for Germany; OECD (2005), Economic Survey of China, OECD, Paris.

Industries dominated by public sector firms appear not to have seen the same gains in efficiency as the result of foreign competition. The profits in public manufacturing firms have risen this decade, but the share of their operating surplus in net value-added remains below that of private sector companies and the rate of return on capital is even lower as public-sector firms tend to be more capital-intensive. Efficiency 
may also be adversely affected in a limited number of industries due to very high concentration and the presence of dominant public sector firms. There are eight industries where the public sector accounts for more than half of output and which are highly concentrated (Table 3, bottom panel): shipbuilding, milling machinery, electric motors, gas turbines, basic fertilizer chemicals, paraffin wax, stainless steel and certain electronic components. Moreover, in three of these industries there is only one public sector company and each has a market share averaging $90 \%$. This high degree of monopoly power complicates the process of privatisation in these cases, especially given the lack of a competition framework until recently (see OECD, 2007). In general, though, public-sector companies in manufacturing are not in concentrated sectors.

More fundamentally, the state or publicly-controlled commercial sector in India remains relatively large, at one-seventh of total GDP and one-fifth of non-farm business sector output, even after the substantial decline seen in the 1990s. Most of this decline was in manufacturing and, by 2004, the share of the public sector in manufacturing output was similar to its share in the aggregate non-farm business sector. Non-manufacturing network industries have much higher shares of public ownership (see OECD, 2007).

Outside of India, there is little debate about the merits of private ownership. However, until recently this has not been reflected in research on India. For example, Mohan (2005) has questioned the superior performance of private ownership despite the exhaustive survey of the international literature by Megginson and Netter (2001). While some studies of private versus public ownership do not fully take account of methodological issues such as selection biases, Megginson and Netter's review of over a hundred studies concludes that even after controlling for this bias, private ownership is more efficient than public ownership under most circumstances. This appears to be the case as well in India, where profitability of public enterprises is low relative to the private sector (Figure 8).

Figure 8. Rate of return on assets, public and private firms, 2004

Per cent

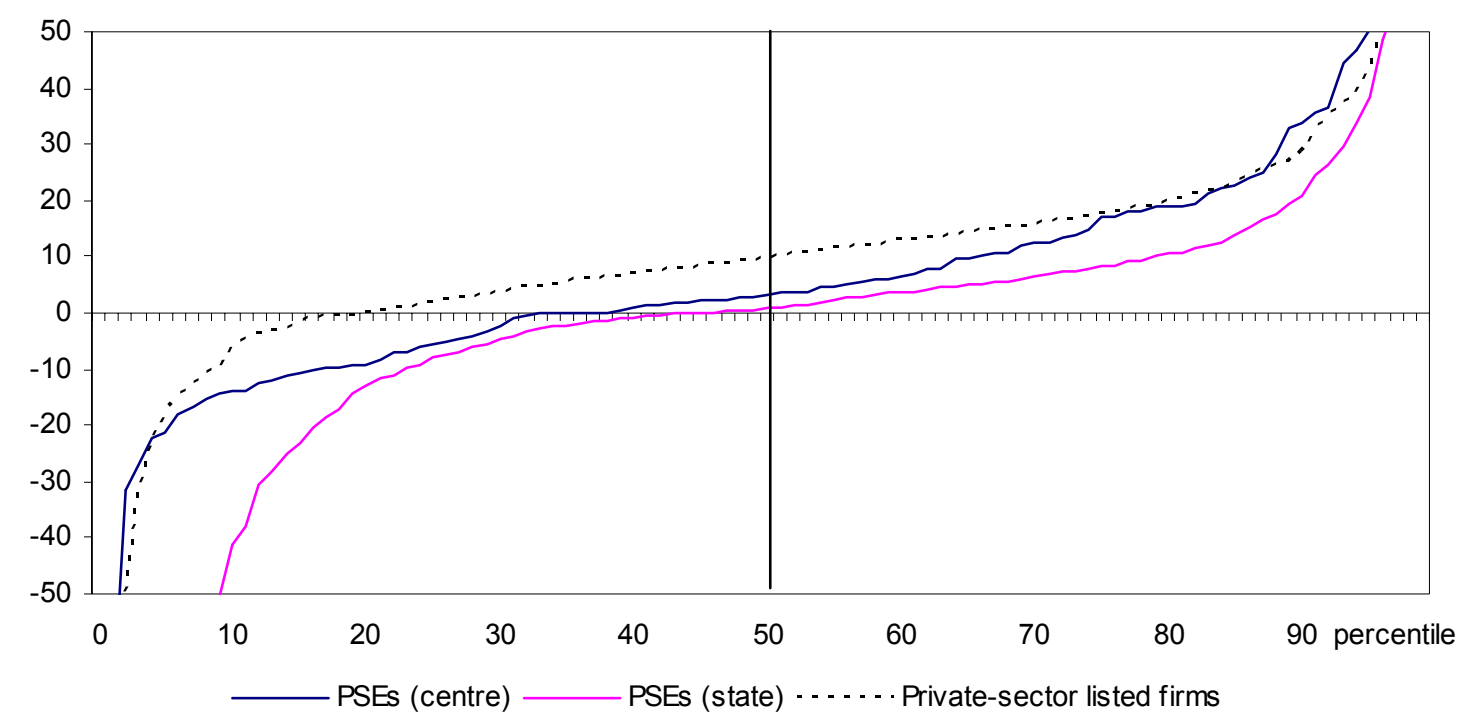

Source: Conway and Herd (2008).

The India-specific studies, such as Gupta (2005), find that even partial privatisation has tangible benefits for investment, productivity, profits and even employment. The few dozen privatisations that have 
occurred in India have been successful, but little forward movement on privatisation has occurred, perhaps on account of vested interests and the role of public firms in fostering political patronage (Dinc and Gupta, 2005). There is certainly some warranted concern that the privatisation of large firms with diversified shareholding structures may see the transfer of assets and income to controlling shareholders, but this argues for a more pro-active stance by stock exchanges (and courts) in their enforcement of corporate governance codes rather than for the government to retain control.

Estimates by the OECD of the productivity performance of private and public firms suggest that there is a clear advantage for private ownership in India. While a simplistic production function approach, without controlling for other factors, indicates that public firms have $10 \%$ higher productivity than private firms, a more rigorous analysis which controls for productivity differences across sectors shows that private firms are on average as much as $33 \%$ more productive than public enterprises. This analysis is based upon regression estimates of productivity on a panel of firms over the 1990-2006 period, including all firm observations regardless of when the firms began or ended operations. ${ }^{12}$ Evidence suggests that weaknesses in framework conditions are at fault.

\section{Conclusion}

In trying to understand why India's manufacturing sector has not been more dynamic, perhaps the most persuasive explanation is that anti-competitive regulations have deterred firms' expansion and the entry of new firms. A number of national and international business surveys suggest that weaknesses in India's business environment have inhibited investment, thus reducing growth and employment creation.

Surveys by business associations of manufacturing firms, asking them to state the most important barriers to investment and expansion, typically feature labour regulation and restrictive exit policies at the top of the list (FICCI, 2004; CII, 2006). Meetings by the OECD 2007 Economic Survey team with groups of business and union representatives, as well as government officials in a large number of states, confirmed that these problems remain dominant, among others, ${ }^{13}$ and indicate that considerable costs are incurred by business and labour as a result of either following or avoiding the regulations.

More perception-based evidence comes from a series of investment climate surveys undertaken under the aegis of the World Bank (World Bank, 2004). These large-scale surveys of firms across 12 Indian states find considerable differences in investors' perceptions of the business environment. Measures of these perceptions are used in related work to examine the linkages between the perceptions and actual investment flows across states.

Drawing upon the World Bank's investment climate survey, Veeramani and Goldar (2005) examine the effect of the investment climate on state-level TFP in manufacturing. In their regression analysis, they find that the state-level investment climate is a strong determinant of productivity performance over the 1980 to 2000 period. However, they also find evidence that states with more pro-worker labour legislation experienced lower productivity growth, a finding that is explored in greater depth in Dougherty (2008). The interface between business and government is a particular source of concern. Survey reports also indicate that business people in India spend more time dealing with government bureaucracy in comparison to OECD and other Asian countries, including China (World Bank-CII, 2004).

12. This estimate follows the same approach described in footnote 7 , with the addition of dummy variables for ownership type.

13. Other major problems cited include infrastructure deficiencies, delays in obtaining approvals, low quality public education and training programs, and taxation of trade. 
Related evidence using detailed establishment-level survey data also suggests that the business environment has a major impact. This is troubling in some respects since the World Bank finds that India ranks $134^{\text {th }}$ out of 175 countries in the overall ease of doing business in 2006 . However, it has made more progress than other South Asian nations in improving its investment climate between 2003 and 2006 (World Bank, 2007). An analysis of manufacturing plant productivity across 40 Indian cities shows that gaps in productivity could to a large extent be explained by differences in regulation and city-level economic geography (Lall and Mengistae, 2005). As well, the study shows that individual plants' perception of labour restrictions had a strong impact on their productivity. This echoes results from comparative studies of Asian countries (Dollar et al., 2005), and suggests that firms consider the specific aspects of the local investment climate in choosing locations. These include: the relative cost of business regulation; the cost of corruption; how intrusively industrial regulations are enforced; the cost and reliability of power supply; and the ease with which land rights can be secured for business premises. While these types of analysis are able to differentiate some aspects of the regulatory environment, they are more useful in highlighting areas of importance than in suggesting what specific types of regulatory reforms need to be undertaken.

Such perceptions by business of the importance of the regulatory environment and the stringency of labour laws may or not play out in practice. Yet rigorous empirical analysis from both aggregate studies of investment patterns across states as well as micro-studies of new investment projects suggests that indeed they make a difference. Micro-evidence, which looks at individual investment decisions, may be the most compelling. For example, Sanyal and Menon (2005) find that the choice of where to place individual new investment projects (during 1997-2001) was significantly affected by the local business environment in each state, and especially by the extent of labour regulation and the climate of labour relations. Other factors such as infrastructure were also important, but the business environment made the most difference. ${ }^{14}$

Given the importance of framework conditions for economic performance in India as a whole and in the individual states, more information is needed which is not only based on perceptions but on the factual regulatory settings in the various areas. For this purpose the OECD's comprehensive indicator, which measures product market regulations across countries, has been constructed for India as a whole and for most of India's states. The main results of this work are presented in the OECD (2007) and Conway and Herd (2008), with a similar exercise for labour regulations undertaken in OECD (2007) and Dougherty (2008), using the OECD's employment protection legislation index and a state-level analogue.

14. What is important to note is that regardless of the labor flexibility that may or may not exist in practice, legislative inflexibility appears to deter new investment. This point has been recognised by a number of observers but does not yet appear to have helped to build a consensus for reform (Tendulkar, 2003). 


\section{BIBLIOGRAPHY}

Aghion, P, R. Burgess, S. Redding and F. Zilibotti (2006), "The Unequal Effects of Liberalization: Evidence from Dismantling the License Raj in India", NBER Working Paper No. 12031.

APO (2004), “Asia Pacific Productivity Data \& Analysis”, in Government of India, Annual Report 2005, Ministry of Labour, pp. 39-43.

Ark, B. van and M. Timmer (2003), "Asia's Productivity Performance and Potential: The Contribution of Sectors and Structural Change", Paper presented at the RIETI-KEIO Conference on the Japanese Economy: Leading East Asia in the 21st Century?, Tokyo, May.

Ark, B. van, J. Banister and C. Guillemineau (2006), "Competitive Advantage of 'Low-Wage' Countries Often Exaggerated", The Conference Board, Executive Action, Series No. 212, October.

Bai, C.-E., Y. Du, Z. Tao, and S. Y. Tong (2004), "Local Protectionism and Regional Specialization: Evidence from China's Industries", Journal of International Economics, No. 63.

Balakrishnan, P. and M. S. Babu (2003), "Growth and Distribution in Indian Industry in the Nineties", Economic and Political Weekly, November 20, pp. 3997-4005.

Banerjee, A. and E. Duflo (2005), "Growth Theory Through the Lens of Development Economics", in P. Aghion and S. Durlauf (eds.), Handbook of Economic Growth, Elsevier Science, North Holland, Amsterdam.

Banerjee, A. (2006), "The Paradox of Indian Growth: A Comment on Kochhar et al.", Journal of Monetary Economics, Vol. 53, No. 5.

Bartelsman, E. and M. Doms (2000), "Understanding Productivity: Lessons from Longitudinal Microdata", Journal of Economic Literature, Vol. 38, No. 3, pp. 569-594.

Batra, A. and Z. Khan (2005), "Revealed Comparative Advantage: An Analysis for India and China", ICRIER Working Paper No. 168.

Bhaumik, S. K., S. Gangopadhyay and S. Krishnan (2006a), "Reforms, Entry and Productivity: Some Evidence from the Indian Manufacturing Sector", Indian Development Foundation Working Paper No. 0602 and IZA Discussion Paper No. 2086.

Bhaumik, S. K., S. Gangopadhyay and S. Krishnan (2006b), "Policy, Economic Federalism, and Product Market Entry: The Indian Experience", William Davidson Institute Working Paper No. 843.

Bosworth, B. and S. Collins (2008), "Accounting for Growth: Comparing China and India", Journal of Economic Perspectives, Vol. 22, No. 1, pp. 45-66. 
Burgess, R. and A. Venables (2004), “Toward a Microeconomics of Growth”, World Bank Policy Research Working Paper No. 3257.

Chari, A. and N. Gupta (2006), "Incumbents and Protectionism: The Political Economy of Foreign Entry Liberalization", Paper presented at the Darden-World Bank Conference on Financing of Corporations in Emerging Countries, April.

CII (2006), "15 Years of Economic Reforms in India: Success \& Progress", Communiqué, Survey Series No. 1, Confederation of Indian Industry, New Delhi.

Conway, P. and R. Herd (2008), "Product Market Regulation in India: An International and Cross-State Comparison”, OECD Economics Department Working Paper No. 599.

Dinc, S. and N. Gupta (2005), "The Decision to Privatize: The Role of Political Competition and Patronage", SSRN Working Paper, http://ssrn.com/abstract=735763.

US DOJ-FTC (1992), Horizontal Merger Guidelines, US Department of Justice and the Federal Trade Commission, www.usdoj.gov/atr/public/guidelines/horiz_book/hmg1.html.

Dollar, D., M. Hallward-Driemeier and T. Mengistae (2005), "Investment Climate and Firm Performance in Developing Economies", Economic Development and Cultural Change, Vol. 54, No. 1, pp. 1-31.

Dougherty, S. and R. Herd (2005), "Fast-Falling Barriers and Growing Concentration: The Emergence of a Private Economy in China", OECD Economics Department Working Paper No. 471.

Dougherty, S., R. Herd and P. He (2007), “Has a Private Sector Emerged in China's Industry? Evidence from a Quarter of a Million Chinese Firms", China Economic Review, Vol. 18, No. 3.

Dougherty, S. (2008), "Labour Regulation and Employment Dynamics at the State Level in India", OECD Economics Department Working Paper, No. 524.

Epifani, P. (2003), “Trade Liberalization, Firm Performance, and Labor Market Outcomes in the Developing World: What Can We Learn from Micro-Level Data?”, World Bank Policy Research Working Paper No. 3063.

Erumban, A. (2007), "Productivity and Unit Labor Cost in Indian Manufacturing: A Comparative Perspective", University of Groningen, GGDC Research Memorandum GD-96.

FICCI (2004), "FICCI Survey on Priority Issues for National Manufacturing Competitiveness Council", Federation of Indian Chambers of Commerce \& Industry, August.

De Vries, G. and M.P. Timmer (2007), “A Cross-Country Database for Sectoral Employment and Productivity in Asia and Latin America, 1950-2005", University of Groningen, GGDC Research Memorandum GD-98.

GOI (2006), Economic Survey 2004-2005, Ministry of Finance, Government of India, http://indiabudget.nic.in/es2004-05/esmain.htm.

Dumais, G., G. Ellison and E. Glaeser (2002), "Geographic Concentration as a Dynamic Process", The Review of Economics and Statistics, Vol. 84, No. 2, pp. 193-204. 
Goldar, B. (2004), "Indian Manufacturing: Productivity Trends in Pre- and Post-Reform Periods", Economic and Political Weekly, 20 November, pp. 5033-43.

Goldar, B. and A. Kumari (2003), "Import Liberalisation and Productivity Growth in Indian Manufacturing Industries in the 1990s", The Developing Economies, Vol. 41, No. 4, pp. 436-60.

Gupta, N. (2005), "Partial Privatization and Firm Performance", The Journal of Finance, Vol. 60, No. 2, pp. 987-1015.

Heston, A. and R. Summers (1992), "Measuring Final Product Services for International Comparisons", in Zvi Griliches (ed.), Output Measurement in the Service Sectors, University of Chicago Press, Chicago and London.

Hoover, E.M. (1936), "The Measurement of Industrial Localization", Review of Economics and Statistics, Vol. 18, No. 4, pp. 162-171.

Hsieh, C. T. and P. Klenow (2007a), "Relative Prices and Relative Prosperity", American Economic Review, Vol. 97, Vol. 3, pp. 562-585.

Hsieh, C. T. and P. Klenow (2007b), "Misallocation and Manufacturing TFP in China and India", NBER Working Paper No. 13290.

Kaur, S. (2006a), "Productivity Growth in Indian Manufacturing: Review of Studies and New Evidence", University of Delhi, Background Report for GOI (2006).

Kochhar, K., U. Kumar, R. Rajan, A. Subramanian, and I. Tokatlidis (2006), "India's Pattern of Development: What Happened, What Follows?", Journal of Monetary Economics, Vol. 53, No. 5, pp. 981-1019.

Kolli, R. and S. Hazra (2005), "Estimation of Informal Sector Contribution in Net Domestic Product", Expert Group on Informal Sector Statistics (Delhi Group), Paper No. 04.

Lall, S. V. and T. Mengistae (2005), "The Impact of Business Environment and Economic Geography on Plant-Level Productivity: An Analysis of Indian Industry”, World Bank, Development Research Group Working Paper No. WPS3664.

McKinsey (2005), “Fulfilling India's Promise”, The McKinsey Quarterly - Special Edition, McKinsey \& Company, Washington, D.C.

Megginson, W. and J. Netter (2001), "From State to Market: A Survey of Empirical Studies on Privatization”, Journal of Economic Literature, Vol. 39, No. 2, pp. 321-89.

Ministry of Finance (2006), Economic Survey 2005-2006, Ministry of Finance, New Delhi, http://indiabudget.nic.in/es2005-06/esmain.htm.

Mohan, TT Ram (2005), Privatisation in India: Challenging the Economic Orthodoxy, RoutledgeCurzon, Delhi, London, and New York.

Mukerji, J. (2006), "Economic Growth and India's Future", University of Pennsylvania, Center for the Advanced Study of India, Occasional Paper No. 26. 
Nagaraj, R. (2004), "Fall in Organised Manufacturing Employment: A Brief Note”, Economic and Political Weekly, 24 July.

Nagaraj, R. (2006), "Public Sector Performance Since 1950: A Fresh Look", Economic and Political Weekly, Vol. 41, No. 25, 24 June.

NBS (2004), China Industrial Census Yearbook, National Bureau of Statistics, Beijing.

NSSO (2001), Migration in India 1999-2000, National Sample Survey Organisation Report No. 470.

OECD (2007), Economic Survey of India, Paris.

Poddar, T. and E. Yi (2007), "India's Rising Growth Potential”, Global Economics Paper No. 152, Goldman Sachs.

Ramaswamy, K.V. (2006), "State of Competition in the Indian Manufacturing Industry", in Pradeep S. Mehta (ed.), A Functional Competition Policy for India, CUTS International, Jaipur and Academic Foundation, Delhi, pp. 155-64.

Ray, S. N. (2004), "Unorganized vis-à-vis Organized Manufacturing Sector in India," Paper presented at the Seminar Series of the Ministry of Statistics and Programme Implementation, November, http://mospi.nic.in/mospi_seminarseries_nov04_3_6_final.pdf.

Sanyal, P. and N. Menon (2005), "Labor Disputes and the Economics of Firm Geography: A Study of Domestic Investment in India”, Economic Development and Cultural Change, Vol. 53, No. 4, pp. 825-854.

Saxena, H. and O. Goswami (2007), “Governance, Investment, and Economic Development: India 1991-2005”, OECD Development Centre Working Paper, forthcoming.

Sivadasan, J. (2003), "Barriers to Entry and Productivity: Micro-Evidence from Indian Manufacturing Sector Reforms", Dissertation, University of Michigan, Graduate School of Business.

Sivadasan, J. (2006), "Productivity Consequences of Product Market Liberalization: Micro-evidence from Indian Manufacturing Sector Reforms”, Ross School of Business Paper No. 1062.

Srivastava, R. and S.K. Sasikumar (2003), “An Overview of Migration in India, Its Impacts and Key Issues", Paper presented in at the Regional Conference on Migration, Development and Pro-Poor Policy Choices in Asia, Dhaka, June.

SSI Census (2003), Third All-India Census of Small Scale Industries 2001-02 (Quick Results), Ministry of Small-Scale Industries, New Delhi, www.smallindustryindia.com/ssiindia/census/sumryres.htm.

Tata (2003), Reforms and Productivity Trends in the Indian Manufacturing Sector, Department of Economics and Statistics, Tata Services Limited, Mumbai.

Tendulkar, S. D. (2003), “Organised Labour Market in India Pre and Post-Reform”, Paper presented at the MacArthur Research Network Conference on Anti-Poverty and Social Policy, Rajasthan.

Topalova, P. (2004), "Factor Immobility and Regional Impacts of Trade Liberalization: Evidence on Poverty and Inequality from India", Three Empirical Essays on Trade and Development in India, Dissertation, Massachusetts Institute of Technology, June. 
ECO/WKP(2008)31

Topalova, Petia (2003), “Trade Liberalization and Firm Productivity: The Case of India”, International Monetary Fund Working Paper No. WP/04/28.

Veeramani, C. and B. Goldar (2005), "Manufacturing Productivity in Indian States: Does Investment Climate Matter?", Economic and Political Weekly, 11 June, pp. 2413-20.

Virmani, A. (2006), "The Dynamics of Competition: Phasing of Domestic and External Liberalisation in India”, Planning Commission Working Paper No. 4/2006-PC.

Virmani, A. and S. Mittal (2006), "Domestic Market Integration", Indian Council for Research on International Economic Relations, Working Paper No. 183.

World Bank and CII (2004), Improving the Investment Climate in India, World Bank, Washington, D.C.

World Bank (2004), India: Investment Climate and Manufacturing Industry, Investment Climate Assessment, World Bank and IFC, Washington, http://tinyurl.com/2td6m8.

World Bank (2006), Doing Business 2007, World Bank, Washington, D.C., www.doingbusiness.org.

World Bank (2007), Doing Business in South Asia 2007, World Bank, Washington, D.C. 
ECO/WKP(2008)31

\section{WORKING PAPERS}

The full series of Economics Department Working Papers can be consulted at www.oecd.org/eco/Working_Papers/

622. Reaping the benefits of stronger competition in network industries in Germany (July 2008) Nicola Brandt

621. The Usefulness of Output Gaps for Policy Analysis (July 2008) Isabell Koske and Nigel Pain

620. Taxation and Economic Growth (July 2008) Åsa Johansson, Christopher Heady, Jens Arnold, Bert Brys and Laura Vartia

619. Coping with labour shortages: How to bring outsiders back to the labour market (July 2008) Ekkehard Ernst

618. Achieving sustainability of the energy sector in Canada (June 2008) Annabelle Mourougane

617. The Dutch tax-benefit system and life-cycle employment. Outcomes and reform options (June 2008) Ekkehard Ernst and Timo Teuber

616. Regulation, Allocative Efficiency and Productivity in OECD Countries: Industry and Firm-Level Evidence

(May 2008) Jens Arnold, Giuseppe Nicoletti, and Stefano Scarpetta

615. Public social spending in Korea in the context of rapid population ageing (May 2008) Randall S. Jones

614. Enhancing the globalisation of Korea

(May 2008) Randall S. Jones and Taesik Yoon

613. Reforming housing and regional policies in Korea

(May 2008) Randall S. Jones and Tadashi Yokoyama

612. Moving towards more sustainable healthcare financing in Germany (May 2008) N. Brandt

611. Improving education outcomes in Germany (May 2008) David Carey

610. Have developed countries escaped the curse of distance?

(May 2008) Hervé Boulhol and Alain de Serres

609. Measures of international transport cost for OECD countries $\mid$ (April 2008) Stephen S. Golub and Brian Tomasik

608. Encouraging labour force participation in Chile (April 2008) D. Contreras, L. de Mello and E. Puentes 
607. Tackling business and labour informality in Chile (April 2008) D. Contreras, L. de Mello and E. Puentes

606. Delivery cost-efficient public services in health care, education and housing in Chile (April 2008) D. Contreras, L. de Mello and E. Puentes

605. Managing Chile's macroeconomy during and after the copper price boom (April 2008) Luiz de Mello

604. Avoiding the value added tax: Theory and cross-country evidence (April 2008) Luiz de Mello

603. Oil Price Shocks, Rigidities and the Conduct of Monetary Policy: Some Lessons from a New Keynesian Perspective (April 2008) Romain Duval and Lukas Vogel

602. The Contribution of Economic Geography to GDP Per Capita (April 2008) Hervé Boulhol, Alain de Serres and Margit Molnar

601. Estimating a supply block for Poland (April 2008) Rafal Kierzenkowski, Patric Ollivaud, Franck Sédillot and Philippe Briard

600. Product market regulation and economic performance across Indian states (March 2008) Paul Conway, Richard Herd and Thomas Chalaux

599. Improving product market regulation in India: an international and cross-state comparison (March 2008) Paul Conway and Richard Herd

598. Revenue buoyancy and its fiscal policy implications (February 2008) Isabelle Joumard and Christophe André

597. Monetary policy, market excesses and financial turmoil (February 2008) Rudiger Ahrend, Boris Cournède and Robert Price

596. Explaining differences in hours worked among OECD countries: an empirical analysis (February 2008) Sven Blondal and Jean-Marc Burniaux

595. Fiscal policy in India: past reforms and future challenges (February 2008) Richard Herd and Willi Leibfritz

594. The significance of Switzerland's enormous current-account surplus (March 2008) Peter Jarrett and Céline Letremy

593. Interdependencies between monetary policy and foreign-exchange intervention under inflation targeting: the case of Brazil and the Czech Republic (January 2008) Jean-Yves Gnabo, Luiz de Mello and Diego Moccero

592. Solow or Lucas? Testing growth models using panel data from OECD countries (December 2007) Jens Arnold, Andrea Bassanini and Stefano Scarpetta 